\title{
Implementation of Push Notification for Business Incubator
}

https://doi.org/10.3991/ijoe.v15i14.11357

\author{
Diky Firdaus $\left({ }^{\square}\right)$, Bagus Priambodo, Yuwan Jumaryadi \\ Universitas Mercu Buana, West Jakarta, Jakarta \\ diky.firdaus@mercubuana.ac.id
}

\begin{abstract}
Push notification of cellular is one of the important features in delivery of information from a mobile application. The push notification feature is provided by firebase cloud messaging in sending notification messages to android devices. The application of push notification on the network for business incubator tenant selection can help improve the process and quality of information distribution in building communication networks and information for startups. This activity is one of the business incubators activities in looking for startups potention and technology products that are deserve to be selected as potential tenants and partners.
\end{abstract}

Keywords - Push notification; firebase; business incubator; tenant selection; startup.

\section{$1 \quad$ Introduction}

In today's digital economy, the government should strive to leverage micro and small businesses by developing suitable policies strategically [18][19][22]. The product need innovation to grow, and business incubator development is an option to help grow innovations and survive in the era of global innovation. Business incubators regulate the incubation process to add the value of incubated products from the technologybased companies to increase the chance of success.

Tenant is a prospective technology-based startup company that is prepared by incubation process to increase the value in facing global business competition. In relation to creating a technology-based startup company, prospective tenants who are prepared to be able to participate in incubation must have the appropriate specifications. One of the ways to get this success is from how the incubator captures business startups through the selection of prospective tenants.

Selection of prospective tenants is one of the activities at the pre-incubation stage, where business incubators seek the startup potential for prospective tenants. Technology products that deserve to be selected become potential tenants that can be used as tenants incubation support. This becomes a strong reason how important to build a good communication and information network for business startups who are consumers of incubators. 
In the today's era of technology, information needs to be used as effectively and efficiently as possible [20]. These needs can be fulfilled by utilizing several Android features. With fulfillment of information, it will be easier to do activities and help human life.

Smartphones user that increase in line with the development of the features, so mobile-based applications are more interactive than websites or other media [21]. One of the Android features in question is push notification. Almost all smartphone applications use this feature. The push notification feature is one of the information technology solution that has the potential to improve the process and quality of information distribution.

The implementation of the push notification on an Android-based app for tenant business incubator selection is expected to be able to improve the process and quality of information distribution to prospective tenants. So that tenant candidates can always follow the activities development that must be followed until the tenant selection and subsequent incubation assistance.

Mobile push notification is an important feature of mobile application and has been widely applied due to the offered mobile computing services [9]. There are various technologies that can be used to develop a notification service, Push notification can be delivered by various methods including standardized protocols (e.g. Server-Sent Events [SSE], the GSM Short Message Service [GSM-SMS], SIPMESSAGE [RFC3428], or OMA Push [OMA-PUSH]), or via browser-specific methods [9]. A significant feature of mobile push services is the real-time notifications to subscribers based on current contexts such as identity, location, status as well as emotions. [10].

Google has begun to migrate its GCM (Google Cloud Messaging) to FCM (Firebase Cloud Messaging) to send message notifications both on the Android platform, or between platforms such as IOS and Chrome. Since Firebase is cross platform therefore allows features of the Firebase circuit deployable in Android, iOS, and the mobile web.

Firebase is a technology that allows us to make web applications with no server-side programming so that development turns out to be easier and quicker. A single Firebase node offers up to 100 connections per second in its free edition. The paid version offers hosting and custom domains for over 3000 INR [5]. Developers can allow Firebase to carry out every necessary step such as verifying users, storing data, and implementing access rules [6]. Firebase stores data in NoSQL and stores data in the form of a paired key [5]. Firebase also allows developers to use Firebase Cloud Messaging feature. Main Capabilities using Firebase Cloud Messaging [3]:

- Send notification messages or data messages

- Versatile message targeting

- Send messages from client app

Firebase provides up to 10 Gigabytes of data transfer throughout your database with an additional 1 Gigabyte as a storage option [5]

Firebase is a cloud-based back-end as a service (BaaS) technology from Google that provides various services, one of which is a push notification feature called firebase cloud messaging. Firebase cloud messaging is a development of Google cloud 
messaging that provides services so that developers can send approved messages to an Android device from the server [2].

FCM implementation includes two main components for sending and receiving messages:

- Trusted environments such as Cloud Functions for Firebase or application servers that will be used to create, target, and send messages

- IOS, Android or Web (JavaScript) client application that receives the message [1]

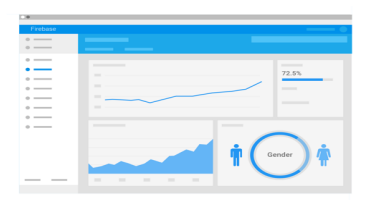

Notifications Console GUI

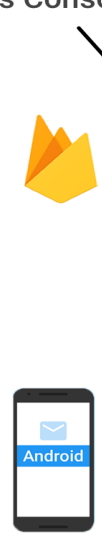

Y

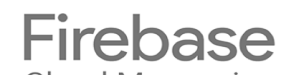

cloud Messaging

Admin SDK

\section{HTTP/XMPP}

Trusted Environment

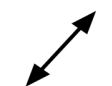

$\downarrow$
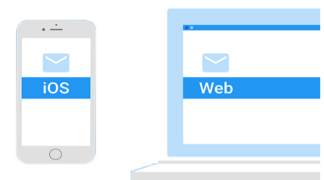

Fig. 1. Firebase cloud messaging Architecture [1]

\section{$2 \quad$ Methodology}

Systems Development Life Cycle (SDLC) is a process to understand how information systems can support business needs through the design of a system. SDLC consists of four fundamental stages, namely planning (planning stage), analysis (analysis stage), design (planning stage), and implementation (implementation phase) [7]. One of the SDLC methodologies most often used in developing a system is the prototyping methodology.

In the prototyping methodology, the analysis, design, and implementation stages are carried out repeatedly (iterative process) to produce a complete system. After conducting initial analysis and design, the system implementation is carried out and produces a prototype system. The system prototype will then be trialed by the user to get feedback 
and be an evaluation material to form a more recent prototype in the next iteration process. This process continues until analysts, users, and sponsors agree to the resulting prototype [7].

Prototyping is the initial example of a concept as part of the product development process. Prototypes represent many goals both from business and technical perspectives. The business prototype is used to collect detailed customer feedback on issues such as aesthetics, ergonomics, and themes, as well as for marketing research and cost analysis. Prototyping is used by engineers to provide manufacturing and assembly data, to investigate system integration problems and to develop analysis and testing strategies. In some cases, prototyping is also used in the phase generation concept of the design process to help designers either expand or contract a collection of possible concepts. So that prototypes are an important part of most design processes.

\section{System Design}

Firebase Cloud Messaging has a messaging solution with many optional additions and new features. One of them is push notification. This platform can provide cloud messaging services accompanied by push notification without server in its architecture, and can send notifications from a Firebase console or a device, to another device.

\subsection{Authentication}

Authentication is process of validating the user's identity. Users are identified using different authentication mechanisms. In a security system the authentication process checks the information provided by the user with the database. If the information matches with the database information, the user is granted access to the security system.[12].

Accountchooser.com is a project of the international non-profit OpenID Foundation, created to make it easier to sign in across the Internet. Entries are stored directly on your device and nowhere else [13].

When a user begins the login flow, the website can opt to redirect to AccountChooser.com, which displays the list of previously used accounts. Once the user selects an account, it is passed along to the website so that it can initiate the login. Google Identity Toolkit automatically integrates with AccountChooser.com to provide a great user login experience, even on the mobile web [13]. 


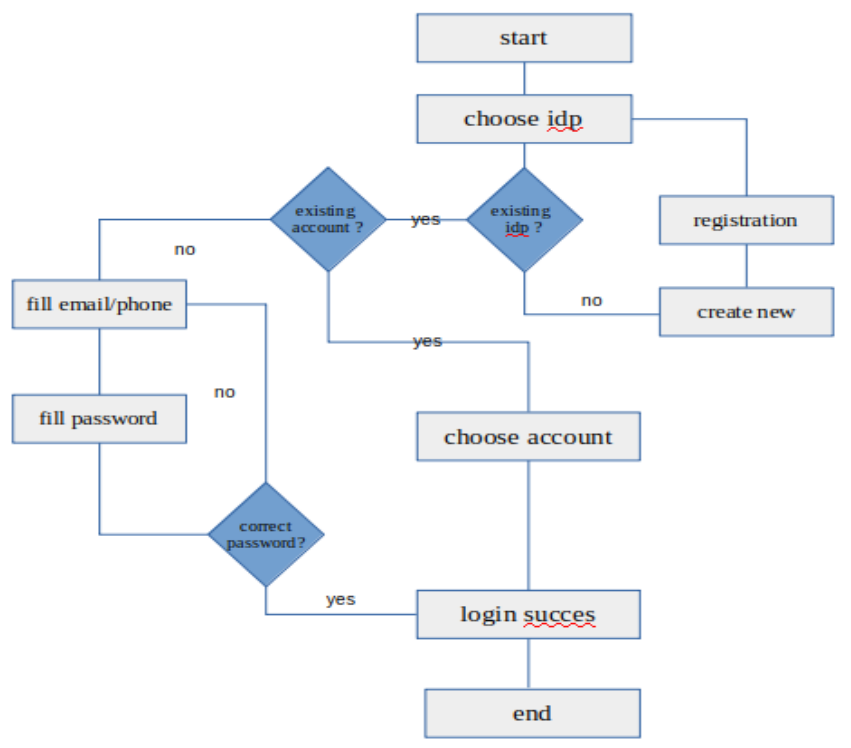

Fig. 2. Architecture authentification [13]

\subsection{Push messaging}

The servlets respond to new user-event logs and process the log data. The servlets use transactions to ensure that only one servlet handles each user-event log [15].

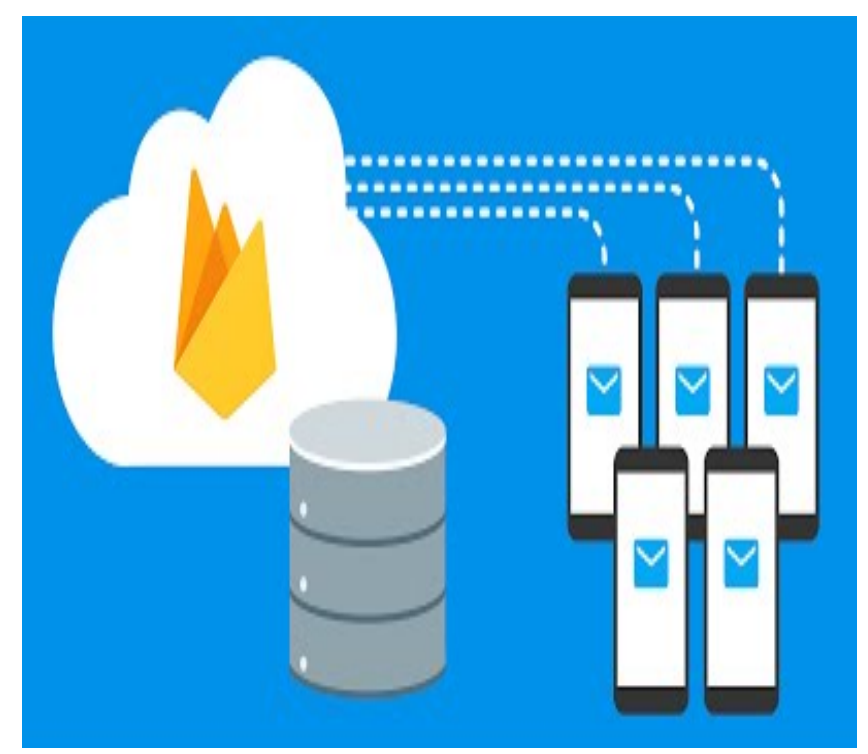

Fig. 3. Architecture of Push Message [15] 
Communication between the app and the servlet happens in three parts:

- When a new user logs into Playchat, the app requests a logging servlet for that user by adding an entry under/inbox/ in the Firebase Real-time Database.

- One of the servlets accepts the assignment by updating the value of the entry to its servlet identifier. The servlet uses a Firebase transaction to guarantee that it is the only servlet that can update the value. After the value is updated, all other servlets ignore the request

- When the user logs in, logs out, or changes to a new channel, Playchat logs the action in /inbox/[SERVLET_ID]/[USER_ID]/, where [SERVLET_ID] is the identifier of the servlet instance and [USER_ID] is a hash value representing the user [15]. The hash function is a function that takes a string of variable-length message and returns a fixed length value called a hash value [17].

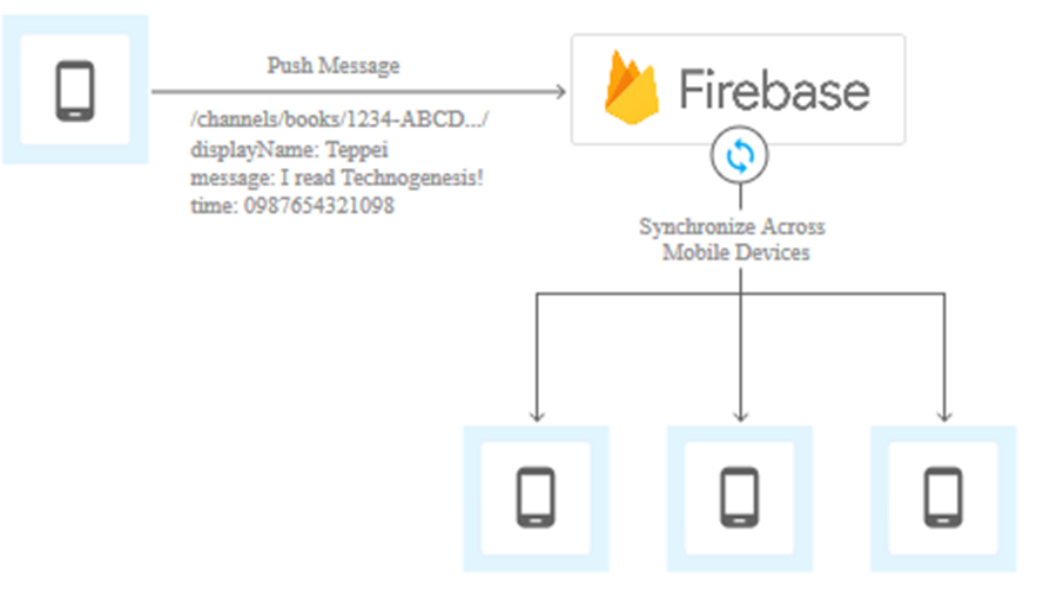

Fig. 4. Push messaging device to device [1]

\subsection{Real-time database}

The database in firebase is a cloud-based database and does not need SQL-based queries to store and fetch data. It is highly reliable thus even if connection is lost data is maintained [15].

The composition of the NoSQL database that will be built has the following architecture:

Database Prostartup

- +Profiles

- +Evidence 
- +Notification

- +Todo

Information: Table profile contains the identity of prospective tenants who are application users. This table contains identities including: id user, email, username, photo.

Table of evidence contains evidence of the prospective business development of tenants, namely: evidence, title, description, image, id user.

Table of assessment contains responses or ratings from the reviewer incubator. This table contains assessment, text assessment, id user.

Table of notification contains notifications that will be received by prospective tenants, the notification aims to remind tenants about information or activities that must be done. This table contains: identification, text notification, id user.

\section{Implementation}

Implementation is taken in two views, that is from the side of Android and Firebase. Implementation includes authentication, database and push notification execution.

Application test is done by the black box method to observe the result of execution through test data and check the functionalities of the application. The test only evaluates the interface, functionality, input and output without knowing the detail process detail and source code in it.

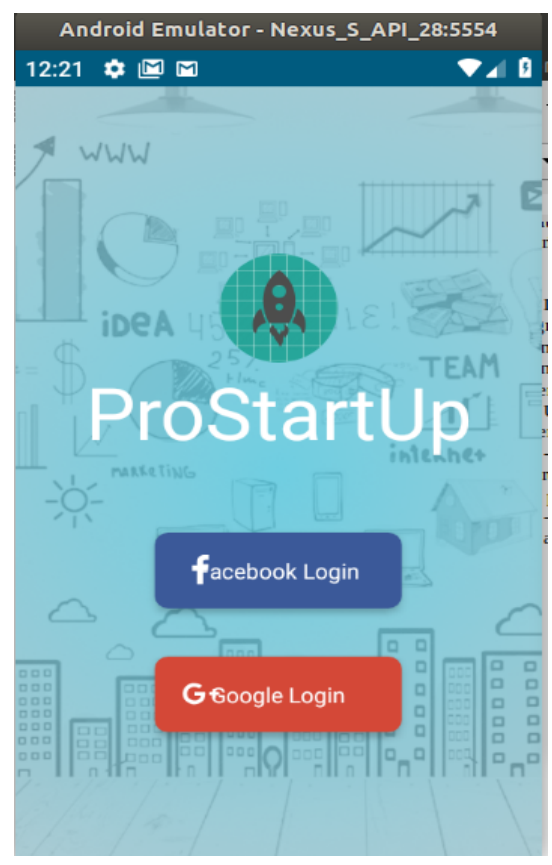

Fig. 5. Login page 
Login and registration is started by authentication with accountchooser.com through the ownership of a Gmail or Facebook account. accountchooser.com make it easy to $\log$ in and register into the application. Login will enter automatically with a password request from the user's Gmail or Facebook account.

\section{Choose account for ProStartUp}

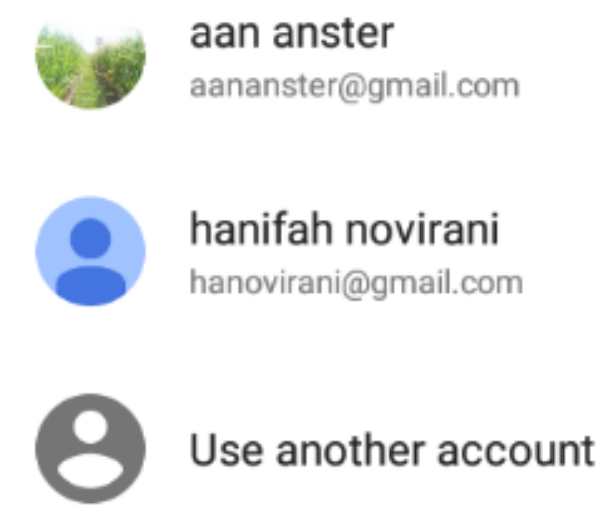

Fig. 6. Account chooser display

The application will point to the main page of the application to access the next pages. The push notification display appears on the main page and profile page of the prospective tenant.

\begin{tabular}{|c|c|c|c|c|c|c|c|}
\hline & & & & & & Create experiment & Notifikasi baru \\
\hline & Notifikasi & Status (2) & Platform & Mulai/Kirim & Akhiri & Terkirim & Terbuka \\
\hline$>$ & $\begin{array}{l}\text { Seleksi TenantF } \\
\text { Jadwal Seleksi Tenant II } 10 \text { Dese... }\end{array}$ & $\checkmark$ Selesai & 뽐 & $\begin{array}{l}31 \text { Des } 2018 \\
11.26\end{array}$ & - & $<1000$ & $20 \%$ \\
\hline$>$ & $\begin{array}{l}\text { Seleksi TenantE } \\
\text { Jadwal Seleksi Tenant II } 10 \text { Dese... }\end{array}$ & $\checkmark$ Selesai & 뜸 & $\begin{array}{l}31 \text { Des } 2018 \\
11.12\end{array}$ & - & $<1000$ & $0 \%$ \\
\hline
\end{tabular}

Fig. 7. Cloud messaging screen display 
Push notification is sent via cloud messaging, which the service provided by Firebase. The Firebase service allows application to be more powerful, safe, and easy to develop.

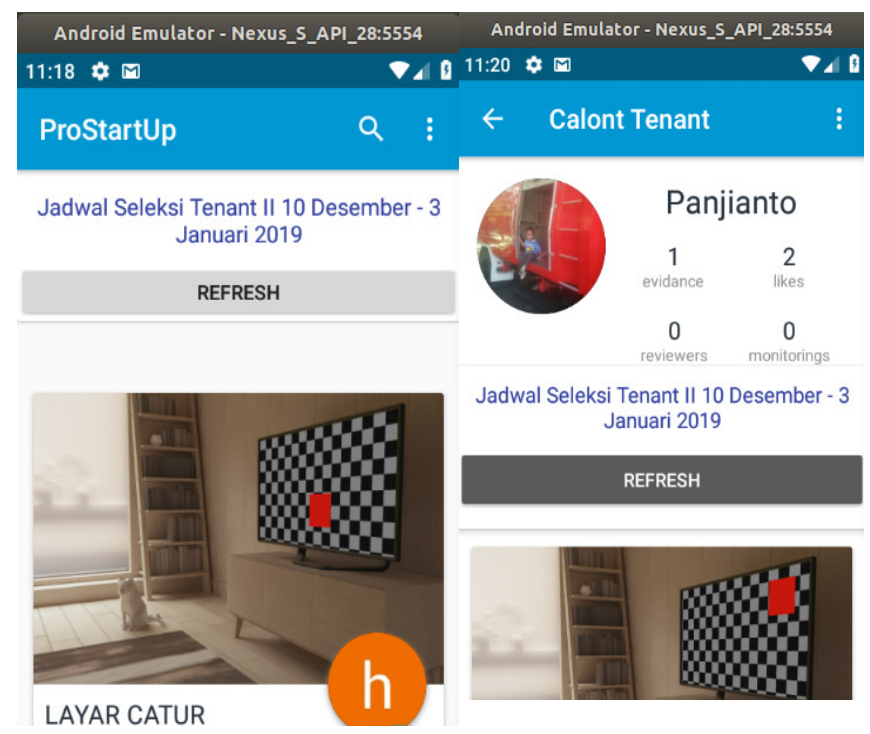

Fig. 8. Notification screen display

Push notification display appears on the main page and profile page of the prospective tenant. Push Notification will change if there is a new notification.

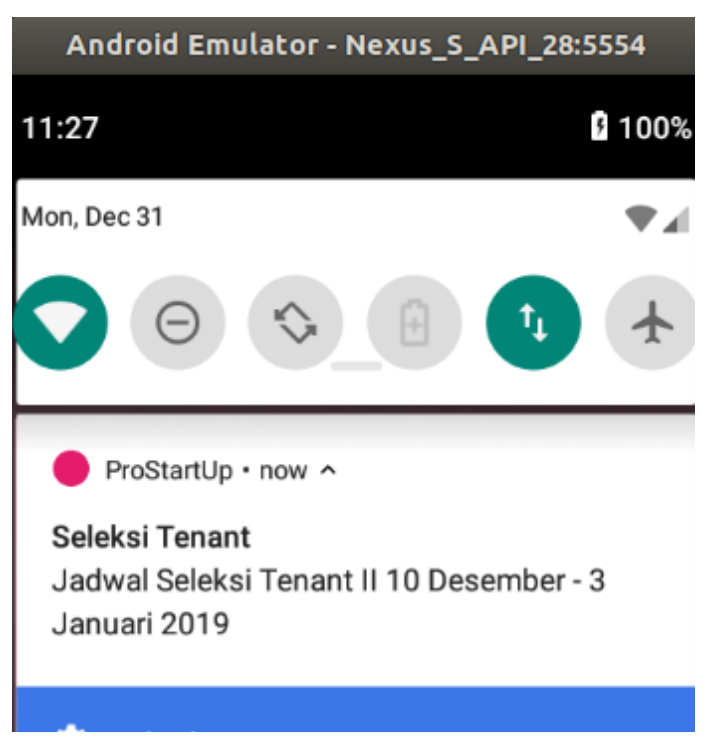

Fig. 9. Push notification 
Push notification will appear a while after being sent from firebase in the application background via the notification feature. Notification feature displays icon, label notification and fill notification.

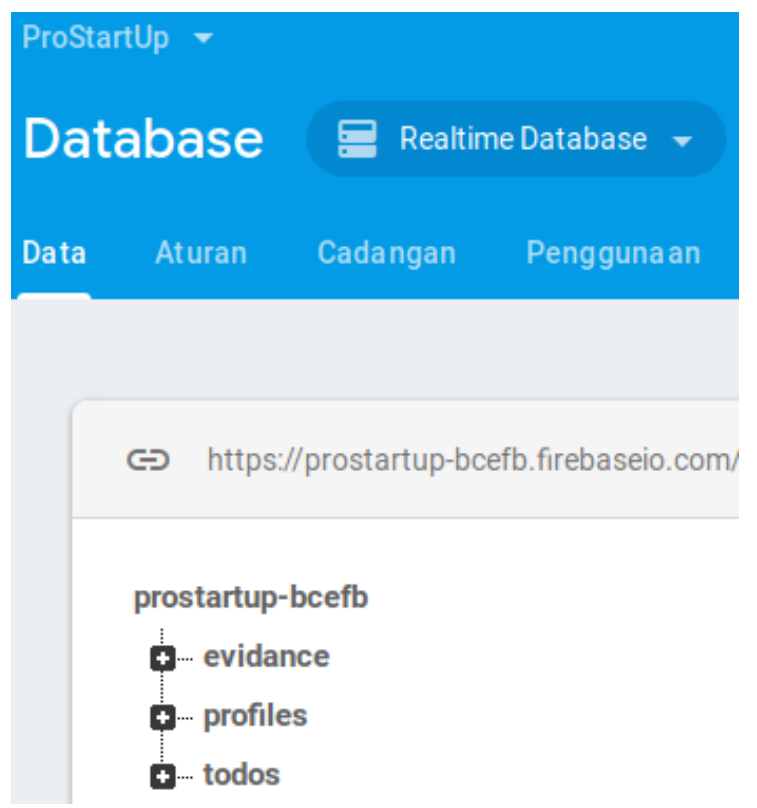

Fig. 10. NoSQL database display

The database stores and synchronizes data between users and devices in a global scale using the NoSQL database. Firebase support services allow the database to run without a server. And the database is still running in real time as long as the application is connected to the internet.

\section{Conclusion}

The push notification service can support the delivery of information on the implementation of incubation to prospective tenants to increase effectiveness and efficiency.

Communication of reviewers, assistants or facilitators with tenants is easier by sending assessment directly to evidence.

- The application still needs to be developed at the user level

- Upload documents / evidence facilitates the track record of prospective tenants

\section{$6 \quad$ References}

[1] Google Developer (November 28th, 2018) Firebase Cloud Messaging. Available: https://firebase.google.com/docs/cloud-messaging/ 
[2] Y. S. Yilmaz, B. I. Aydin, M. Demibras, Google Cloud Messaging (GCM): An Evaluation, IEEE GLOBECOM. Dec 8-2012, 2014. https://doi.org/10.1109/GLOCOM.2014.7037233

[3] Neha Saxena, Suhasini Maurya, Ankit Rai, Santosh Yadav, Jinesh Malavia, "Go Mumbai," International Journal of Computer Science Trends and Technology (IJCST). Vol. 5 Issue 2, April 2017, pp 165-168.

[4] M. Gusev and S. Ristory, "Alert notification as service", Croatia, 2014. http://dx.doi.org/10.1109/mipro.2014.6859584 https://doi.org/10.1109/MIPRO.2014.6859584

[5] Sushant Paygude, Rohit Karadkar, Pratik Joshi, Devender Malhotra, "Be Positive - An Android Application for Blood Donation," International Journal of Scientific Engineering and Technology (IJSET). Vol. 5 Issue 8, pp 418-420.

[6] K.N. Manoj Kumar, Kailasa Akhi, Sai Kumar Gunti, M.Sai Prathap Reddy, "Implementing Smart Home using Firebase," International Journal of Research in Engineering and Applied Sciences(IJREAS). Vol. 6 Issue 10, October - 2016, pp 193198.

[7] Barczak, G., Griffin, A. and Kahn, K. B., 2009, PERSPECTIVE: Trends and Drivers of Success in NPD

[8] Practices: Results of the 2003 PDMA Best Practices Study. Journal of Product Innovation Management, 26: 3-23.

[9] R. Roger.; V. Wright, "Assessing technology's role in communication between parents and middle schools", Electronic Journal for the Integration of Technology in Education,2008, Vol 7,pp. 36-58.

[10] Rasha el Stohy, Nashaat el Khamesy, Haitham el Ghareeb, " A Proposed System for Push Messaging on Android," International Journal of Interactive Mobile Technologies (IJIM). Vol. 10 Issue 3,2016, pp 29-34. https://doi.org/10.3991/ijim.v10i3.5567

[11] Gartner, Inc. the world's leading information technology research and advisory company.

[12] N. A Lal, S. Prasad, M. Farik, "A Review of Authentication Methods," International Journal of Scienctific and Technology Research (IJSTR). Vol. 5 Issue 11, November 2016, pp 246249.

[13] Account chooser (2016). [Online]. What is the OpenID account chooser? Available: https://www.accountchooser.com/learnmore.html

[14] Google Developer (August us 4th, 2017) Identity Toolkit. Available: https://developers.google.com/identity/toolkit/

[15] Google Cloude (September 18th, 2018) Firebase Cloud Messaging. Available: https://cloud.google.com/solutions/mobile/mobile-firebase-app-engine-flexible

[16] S. Khedkar, S. Thube, " Real Time Databases for Applications," International Research Journal of Engineering and Technology (IRJET). Volume: 04 Issue: 06, June 2017, pp 20782082.

[17] Ida Nurhaida, Desi Ramayanti, Rhema Riesaputra, "Digital Signature \& Encryption Implementation for Increasing Authentication, Integrity, Security, and Data Non-Repudiation," International Research Journal of Computer Science (IRJCS). Vol 4 Issue 11 November 2017. pp 5-14.

[18] Bani Pamungkas, Siti Rohajawati, Devi Fitrianah, Ida Nurhaida, H.H. Wachyu (January 2018), "Proposing a Key Model E-Commerce Towards Digital Economy for Coastal Areas in Indonesia," Research gate. Available: https://doi.org/10.1007/978-981-10-6454-8 14

[19] Watjanarat Kuandee. 2019. Asset Supply Chain Management System-based IoT Technology for Higher Education Institutions. International Journal of Online and Biomedical Engineering (iJOE). https://doi.org/10.3991/ijoe.v15i03.8533

[20] Olga Smolyaninova, and Ekaterina Bezyzvestnykh. (2019) Implementing Teachers' Training Technologies at a Federal University: E-portfolio, Digital Laboratory, PROLog Module 
System. International Journal of Online and Biomedical Engineering (iJOE). https://doi.org/10.3991/ijoe.v15i04.9288

[21] Hery Harjono Muljo, Anzaludin Samsinga Perbangsa, Yulius Lie, Bens Pardamean. Improving Early Cancer Detection Knowledge through Mobile Learning Application. International Journal of Online and Biomedical Engineering (iJOE) Vol 15, No 02 (2019). https://doi.org/10.3991/ijoe.v15i02.9678

[22] Priambodo, B., Ani, N., Jumaryadi, Y. (2018). An efficient and affordable push strategy of mobile advertising for micro enterprises. Internetworking Indonesia Journal, Volume 10, Issue 2, 2018, Pages 43-48

\section{$7 \quad$ Authors}

Diky Firdaus is a lecturer at the Faculty of Computer Science, Universitas Mercu Buana. E-mail id: diky.firdaus@mercubuana.ac.id

Bagus Priambodo is a lecturer at Department of Information Systems, Faculty of Computer Science, Universitas Mercu Buana, Jakarta, Indonesia. He is working on EBusiness and Mobile Application at the E-Business Laboratory, Department of Information Systems, Faculty of Computer Science, Universitas Mercu Buana, Jakarta, Indonesia. Email: bagus.priambodo@mercubuana.ac.id

Yuwan Jumaryadi is a lecturer at Department of Information Systems, Faculty of Computer Science, Universitas Mercu Buana, Jakarta, Indonesia. He is working on ECommerce at the E-Business Laboratory, Department of Information Systems, Faculty of Computer Science, Universitas Mercu Buana, Jakarta, Indonesia. E-mail id: yuwan.jumaryadi@mercubuana.ac.id

Article submitted 2019-07-23. Resubmitted 2019-08-27. Final acceptance 2019-08-27. Final version published as submitted by the authors. 